\title{
Determination of the heating pile numerical model parameters based on the laboratory strength tests of clay at low temperatures
}

\author{
BARTOSZ PIOTROWICZ, MAŁGORZATA JASTRZĘBSKA, \\ MARIAN ŁUPIEŻOWIEC \\ Faculty of Civil Engineering, Silesian University of Technology, Gliwice, Poland
}

\begin{abstract}
Determination of the heating pile numerical model parameters based on the laboratory strength tests of clay at low temperatures. Heating piles combine the function of the foundation and the heat source. They acquire heat from the ground through in built the installation. Inside the installation is non-freezing liquid at low temperature. In connection with the above, piles and the surrounding soil are exposed to significant temperature changes. As a result of these changes, the mechanical parameters of the soil and the behavior of the pile and soil contact surface were changed. This affects directly the load capacity of the heating piles. To describe this effect, laboratory tests were carried out to determine the thermal and mechanical parameters of the soil at low temperatures. The results from laboratory tests were applied as material parameters in the $Z_{-}$Soil program. Based on the analysis using the finite element method, it was found that there is an negative effect on the friction on the surface of pile associated with the heat transfer between the soil and the pile.
\end{abstract}

Key words: heat piles, heat flow, freezing the ground, numerical analysis, soil strength parameters

\section{INTRODUCTION}

Nowadays, because of the progressive air pollution mainly in the centers of large cities, it is necessary to take measures to improve the energy efficiency of buildings. One of the ways to increase the energy efficiency of building facilities is the use of renewable energy sources (RES). Geothermal energy (of low and high temperature) based on renewable energy sources plays a special role in technologies. It owes its position primarily to the ease of its use for commercial purposes, as well as its large resources available virtually anywhere in the world (Kapuściński and Rodzoch 2010). Energy accumulated in the ground and rocks is possible to be used both for heating buildings and for obtaining warm utility water. In the buildings where foundation piles (FP) are used, they are used as a source of heat too (Jastrzębska and Piotrowicz 2015, Jastrzębska and Wawrzyńczyk 2016). An example of the construction of the object on foundation heating piles (FHP) is the six-storey Techno polis Innova two office complex in the center of Jyvaskyla in Finland, with a usable area of $10,000 \mathrm{~m}^{2}$. During the implementation of this investment about $5 \mathrm{~km}$ of steel foundation piles were made and $1,100 \mathrm{~m}$ of them were piles in which heat exchangers were installed. This solution met the building's demand for 
energy in $50 \%$. The installation can be used for heating and cooling of rooms (Jastrzębska and Wawrzyńczyk 2016). It is worth noting that when the planned construction requires an deep foundation, the installation of a heat exchanger installation in selected foundation piles constitutes a small share in the cost of the entire structure. The technology of heating piles (HP) is also used in construction of single-family houses, although in this case it is referred to an independent heating manifold rather than a hybrid system: a carrier pile with a heat exchanger which is called FPH (Lachmann 2013, Kępińska 2015).

Poland's climate is moderate. There are large temperature differences between the summer and winter periods. The lowest recorded air temperature in Poland over the last 60 years was $-42.2^{\circ} \mathrm{C}$, while the highest temperature was $+40.2^{\circ} \mathrm{C}$ (Mizerski and Żukowski 2001). It means that the amplitude of long-term temperatures is $82.4^{\circ} \mathrm{C}$. In turn, it enforces the heating of rooms in which people stay in winter and at the same time it may mean the rooms need to be conditioned in summer. In such a case, the use of the so-called low temperature geothermal energy in the FPH function is a very beneficial solution, although it has specific consequences. If FPH is used for the foundation of the object, the temperature differences of the soils in the immediate environs of the piles undergo significant fluctuations. Taking this into account, determining the impact of ground temperature changes on its mechanical properties is of great importance for the correct foundation of building structures (Wajman 2011).

One should remember that the soil consists of three phases in which each phase (solid one, liquid one and gas one) reacts differently to temperature changes. Therefore, determining the change of mechanical parameters of soils in function of their temperature is a difficult task (Piętkowski and Czarnota-Bojarski 1964, Pisarczyk 1998). As research conducted by Amis et al. (2008) shows, changes in soil temperature around the exploited FPH affect both the settlement value of the pile during static load as well as its bearing capacity. The difference in settlements between the pile with the heating system turned on and the pile without a functioning installation was about 5\% (Amis 2008). However, these studies were cyclic tests which in fact caused permanent deformations in each cycle. In turn, in the heating and cooling cycles Wang et al. (2017) analyzed in situ the effect of various shapes (U, $\mathrm{V}$ and $\mathrm{W}$ ) of heat exchangers built into the FPH on their settlement as well as on the temperature of the surrounding soil. The tests confirmed that in each heating or cooling cycle the ground temperature changed. In the case of the $\mathrm{W}$ type exchanger, this effect was $0.56 \%$ higher than the others. In addition, in comparison to the control test, the decrease in the pile settlement was noted (Wang 2017). All of these observations prove that the impact of ground temperature changes around the FPH is very important for the proper interaction of piles with the surrounding soil. Hence, the subject of this work is the laboratory identification of changes in strength parameters of clay at low temperatures. The obtained results are the basis for verification of the numerical model of the foundation heating pile in terms of its bearing capacity and displacements. 


\section{MATERIAL AND METHODS}

\section{Heat flow in the ground}

The ground having a considerable thermal capacity does not undergo significant temperature fluctuations in its volume. Amis et al. (2008) indicates the ground also has a large thermal inertia. In the case of a heating pile that extracts heat from the ground, in order to obtain temperature changes at a distance of $2.0 \mathrm{~m}$ from the edge of the pile, it must take 2-3 days of continuous work of the heating installation (Amis 2008). This time depends on the type of soil and water conditions. In addition, after turning off the heating installation, the soil returns to its normal temperature after about 1 week (Amis 2008, Wang 2017). As in each center, the heat flow in the ground is carried out in accordance with the second law of thermodynamics, which says that heat flows from a medium with a higher temperature to one with the lower temperature. In the case of heating piles (HP), this flow results from a much lower temperature of the heating element of the installation (usually glycol) than the temperature of the soil around the pile. This situation forces the flow of heat under its natural direction. If one wants to use the heating system also for the purpose of cooling rooms in summer, the flow direction changes to the opposite. The temperature of the heating medium is higher than the temperature of the ground around the pile. Heat flows from the pile to the ground. According to Plewa (1994) during long and cool winters in Poland, the ground temperature may drop below $0^{\circ} \mathrm{C}$ only in surface layers to a depth of $1.0 \mathrm{~m}$. According to Pająk and Malinowski (2001) regard- less of the season in natural conditions, the temperature of the ground reaches the average annual air temperature at a depth of about $9.0 \mathrm{~m}$. For example, in 1997-1998 this temperature was for Kraków $+8.6^{\circ} \mathrm{C}$. The depth referred to is the so-called depth of the neutral zone temperature. In the scale of the whole of Poland, the thickness of the ground layer in which the temperature reaches the average annual air temperature is from 7.7 to $27.1 \mathrm{~m}$ (Plewa 1994, Pająk and Malinowski 2001). Taking all of the information into consideration, even shallowly located layers of soil constitute a rich source of thermal energy, possible to be used by heat exchangers mounted in foundation piles.

One of the basic tasks of each designer is to estimate the expected efficiency of such a heating system, i.e. determine the ability of the ground to transfer and accumulate heat. For the needs of this task, it is necessary to know the thermal properties of the soil characterized, among others, by thermal conductivity, heat capacity $\left(C_{v}\right)$ and thermal diffusivity $(\alpha)$ (Usowicz 2002, Solis 2004-2009, Stefanowicz and Szulgowska-Zgrzywa 2017). The thermal diffusivity of the soil is a secondary quantity that is a quotient of thermal conductivity and heat capacity per unit volume. It also determines the ability of the soil to equalize temperature at all its points (Usowicz, 2002). The estimation of individual parameters may take place experimentally in laboratory or in situ conditions with the use of a statistical model of thermal conductivity (Usowicz 2002). The thermal response test (TRT) is the most well-known method for evaluation the thermal properties of soil which has 
the function of the lower temperature heat source for heat pumps in natural conditions (Stefanowicz and Szulgowska-Zgrzywa 2017).

\section{Determination of thermal heat capacity of the soil in the laboratory tests}

One of the most important thermal parameters of the soil is its heat capacity $(\lambda)$ expressed in $J / K$. It is a parameter that determines the amount of heat that must be delivered to (or taken from) the ground, so that its temperature changes by $\pm 1 \mathrm{~K}$. The thermal capacity largely depends on the volume fraction of individual components of all soil phases (Usowicz 2002). The idea of a laboratory determination of thermal capacity consists in measuring the temperature changes of the material being examined (in this case the soil represented by clay) that correspond to the amount of heat transfer between two medium (soil and air). Specific investigations were conducted on clay whose moisture content equaled $w=37 \%$ and the liquidity index was $I_{L}=0.23$. A cylindrical soil sample with a diameter equaled $d=35 \mathrm{~mm}$, length $l=200 \mathrm{~mm}$ and mass $m=383.88 \mathrm{~g}$ was prepared. In its center the capillary for temperature measurements was placed (Fig. 1). The prepared sample was placed in a freezer (with nominal cooling temperature $T=-26^{\circ} \mathrm{C}$ ) for a period of 2 weeks, whereby the initial temperature was $T_{0}=-22.4^{\circ} \mathrm{C}$. Then, the sample was placed in a room with temperature $T_{w}=+17.6^{\circ} \mathrm{C}$. Changes in the temperature of the frozen soil and the room were controlled by means of two electronic thermometers with a measurement accuracy of $\pm 0.1^{\circ} \mathrm{C}$.

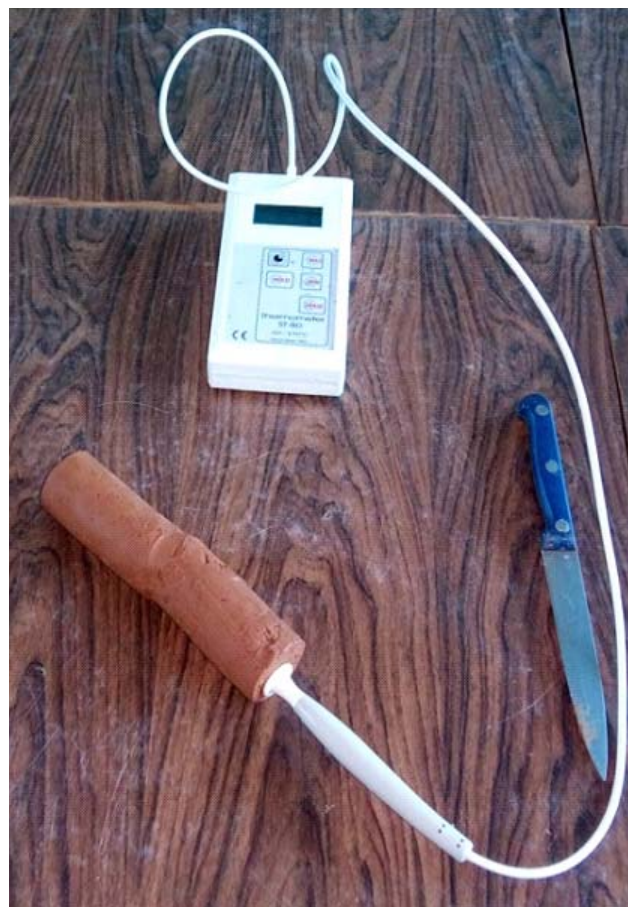

FIGURE 1. The test-bench for measuring changes in the temperature of the frozen soil

The study lasted over $4 \mathrm{~h}$. For the first $10 \mathrm{~min}$, the soil temperature change was recorded every $1 \mathrm{~min}$. The changes at this time were the most intensive (Fig. 2). After this time, the rate of change slowed down. The next readings were recorded every $5 \mathrm{~min}$. The temperature gradient at this time was constant and amounted to $0.6^{\circ} / 5 \mathrm{~min}$. After 20 readings (100 $\left.\mathrm{min}\right)$ it was noticed that the temperature gradient decreased significantly. At temperatures between $-2^{\circ}$ and $+3^{\circ} \mathrm{C}$, it was only $0.2^{\circ} \mathrm{C} / 5 \mathrm{~min}$. After exceeding the temperature of $+3^{\circ} \mathrm{C}$, the temperature gradient was about $0.4^{\circ} \mathrm{C} / 5 \mathrm{~min}$. At the moment of room and soil temperature equalization, the temperature gradient was insignificantly small (Fig. 2). As a result of sampling heat from the 


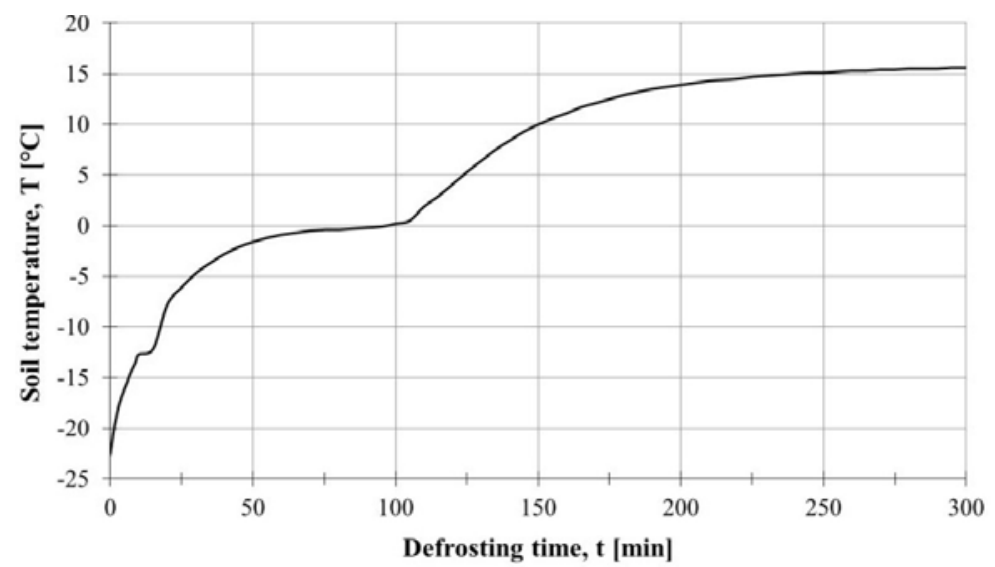

FIGURE 2. Changes in temperature of the defrosted sample in the room temperature of clay at time

air, the temperature in the room did not change. According to the general equation of heat transfer in a confined space, it was estimated that the amount of heat that penetrated into the soil was about $399.0 \mathrm{~kJ} / \mathrm{K}$. This value is the heat capacity of the tested soil. This allows us to calculate the value of specific heat $\mathrm{cw}$ for the tested soil. It is $c_{w} \approx 2,073.6 \mathrm{MJ} / \mathrm{m}^{3} \mathrm{~K}$. The obtained test results are in accordance with Gryglaszewski (2006).

\section{Determination of soil strength parameters in the low temperature - results and discussion}

The research presented below is part of a broad research cycle carried out in interaction with Antosz (2017). Determination of the strength parameters of the clay (angle of internal friction - $\Phi_{U U}$, and cohesion $-c_{U U}$ ) at different temperatures was carried out in the triaxial apparatus in conditions without consolidation or drainage. The choice of the UU type test was dictated by the fact that the pores in the clay were filled with frozen water. The samples tested (Fig. 3) were at room temperature (group A) and at different negative temperature ranges (groups B-D). In order to maintain the negative soil temperature for the entire duration of the test, the triaxial apparatus

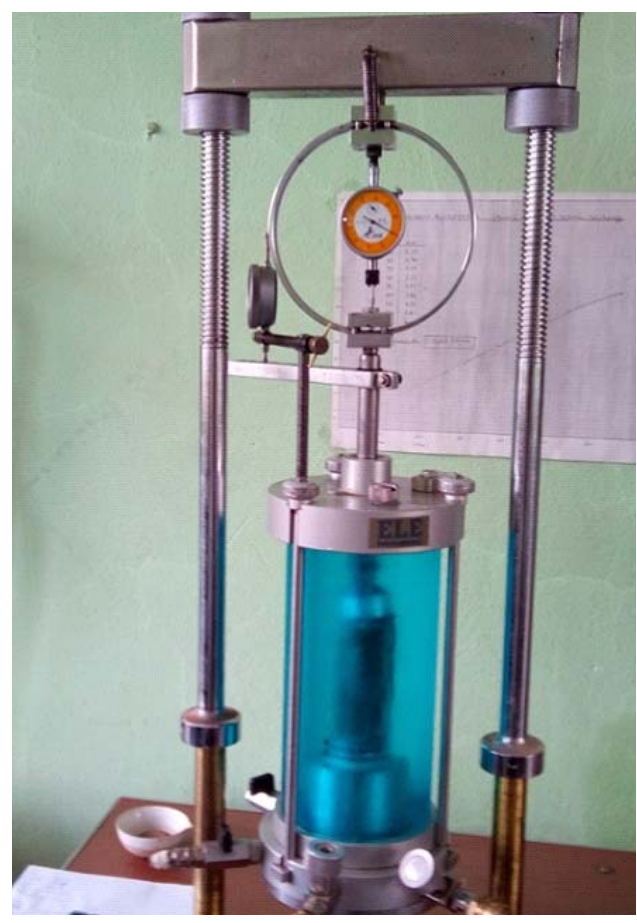

FIGURE 3. The sample of clay prepared for the triaxial test 
cell was filled with a previously cooled anti-freeze aqueous substance mixture: ethyl alcohol $30 \%$ by weight, methyl alcohol $2.9 \%$ by weight and methyl ethyl ketone 2 wt. Despite this and other remedies (covering the cell of a triaxial apparatus with insulating mats or styrofoam), the test conditions were variable because it was not possible to maintain a constant temperature during the shearing.

A series of 16 tests was carried out on cylindrical samples with a diameter of $d=35 \mathrm{~mm}$ and height $h=80-90 \mathrm{~mm}$, at different pressures in the cell $\sigma_{3}=100$, $150,200,250,300$ and $350 \mathrm{kPa}$ (Fig. 4). The shearing rate was $v_{s}=10 \mathrm{~mm} / \mathrm{h}$.

The test results were interpreted in four groups: A, B, C, D. The division criterion was the length of freezing time of individual samples, which turned out to have an impact on their final temperature and strength properties (Table 1). Group A includes control samples tested at room temperature. Group B included samples frozen for 22 weeks and group C for 24 weeks. Soils from group D were tested within 2-4 weeks from the start of freezing and they showed the greatest divergences in the strength parameters obtained. Therefore, it was concluded that these results cannot be treated as meaningful.

In each case of soils from group D, their shear strength in conditions without drainage was higher than that of control group A. On the other hand, clay samples from groups $\mathrm{B}$ and $\mathrm{C}$ showed similar values, which were significantly higher than control group A (Fig. 3). In Table 1 the conditions of individual tests and the received values of the angle of internal

\section{UU triaxial tests for frozen and in room temperature clay specimens}

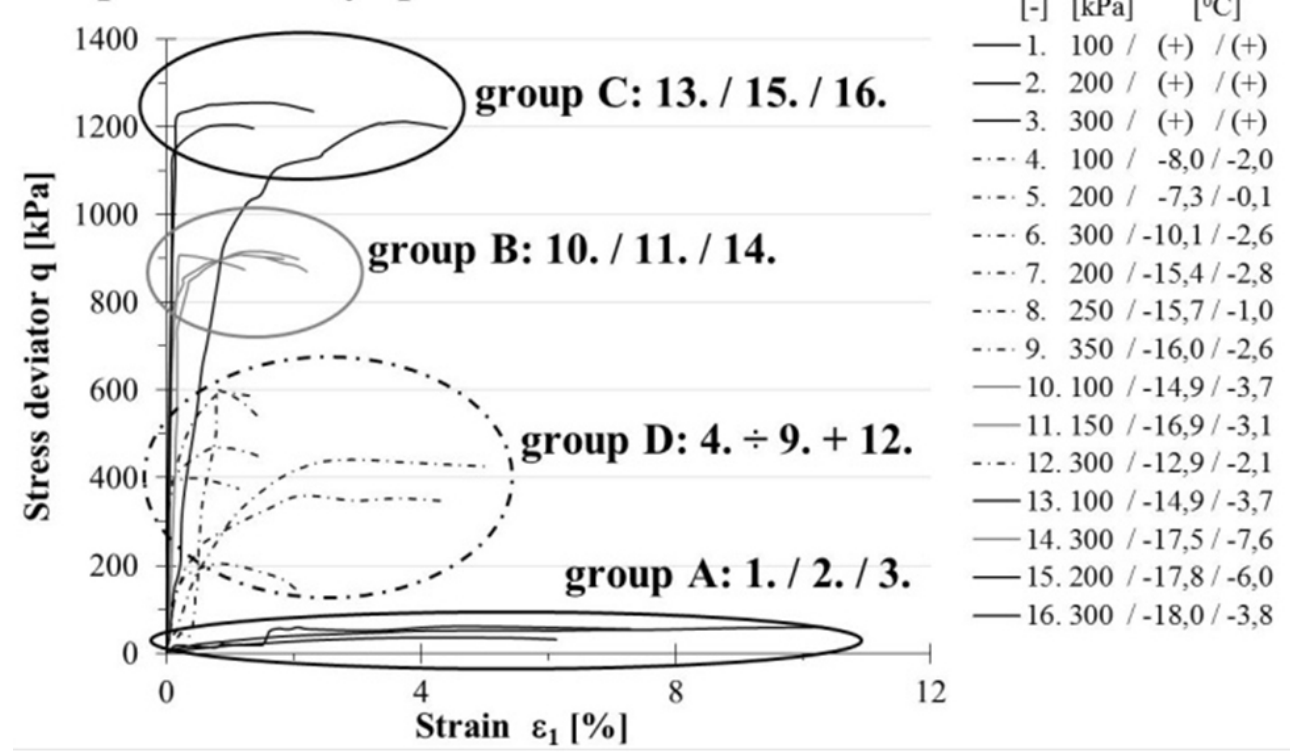

FIGURE 4. Changes in shear strength in UU tests on frozen clay and in room temperature 
TABLE 1. Research conditions and obtained strength parameters of clay

\begin{tabular}{|c|c|c|c|c|c|c|c|}
\hline \multirow{3}{*}{$\begin{array}{l}\text { Group } \\
\text { number }\end{array}$} & \multirow{3}{*}{$\begin{array}{c}\text { Test } \\
\text { number }\end{array}$} & \multirow[b]{2}{*}{$\begin{array}{c}\text { Pressure } \\
\text { in cell } \\
\left(\sigma_{3}\right)\end{array}$} & \multirow[b]{2}{*}{$\begin{array}{c}\text { Sample } \\
\text { moisture } \\
\text { content } \\
(w)\end{array}$} & \multicolumn{2}{|c|}{ Liquid temperature in cell } & \multicolumn{2}{|c|}{ Strength parameters } \\
\hline & & & & $\begin{array}{l}\text { before test } \\
\quad\left(T_{1}\right)\end{array}$ & $\begin{array}{c}\text { after } \\
\text { test } \\
\left(T_{2}\right)\end{array}$ & $\begin{array}{c}\text { internal } \\
\text { friction } \\
\text { angle } \\
\left(\Phi_{U U}\right)\end{array}$ & $\begin{array}{c}\text { cohesion } \\
\left(c_{U U}\right)\end{array}$ \\
\hline & & $\mathrm{kPa}$ & $\%$ & ${ }^{\circ} \mathrm{C}$ & ${ }^{\circ} \mathrm{C}$ & $\circ$ & $\mathrm{kPa}$ \\
\hline \multirow{3}{*}{$\begin{array}{c}\text { A } \\
\text { (control test; } \\
\text { no freezing) }\end{array}$} & 1 & 100 & 36.8 & +17.6 & +17.6 & \multirow{3}{*}{3.46} & \multirow{3}{*}{12.41} \\
\hline & 2 & 200 & 37.1 & +17.4 & +17.4 & & \\
\hline & 3 & 300 & 37.2 & +17.8 & +17.8 & & \\
\hline \multirow{3}{*}{$\begin{array}{c}\text { B } \\
\text { (22 weeks) } \\
\text { of freezing }\end{array}$} & 10 & 100 & 37.0 & -14.9 & -3.7 & \multirow{3}{*}{1.17} & \multirow{3}{*}{442.17} \\
\hline & 11 & 150 & 37.5 & -16.9 & -3.1 & & \\
\hline & 14 & 300 & 37.4 & -17.5 & -7.6 & & \\
\hline \multirow{3}{*}{$\begin{array}{c}\text { C } \\
\text { (24 weeks) } \\
\text { of freezing }\end{array}$} & 13 & 100 & 37.3 & -14.9 & -3.7 & \multirow{3}{*}{0} & \multirow{3}{*}{612.38} \\
\hline & 15 & 200 & 37.2 & -17.8 & -6.0 & & \\
\hline & 16 & 300 & 37.5 & -18.0 & -3.8 & & \\
\hline
\end{tabular}

friction and cohesion are presented. In Table 1 the group D was omitted.

The obtained results show that in the case of frozen soil (max to temperatures $T=-15^{\circ} \mathrm{C}$ ), the obtained strength parameters $\left(c_{U U}, \Phi_{U U}\right)$ were higher than for samples at room temperature. In addition, studies have shown that the values of the determined parameters depend not only on the temperature of the soil and the fluid in the cell during the test, but also on the time of freezing the soil before testing. The longer it is, the stronger the soil's strength. In the case of samples, whose freezing at $T=-26^{\circ} \mathrm{C}$ lasted 22 weeks, the soil cohesion in conditions without drainage $c_{U U}$ was about twice as high as samples frozen for only 2 weeks and over 35 times higher than in the control samples (at room temperature). It is worth noting that for samples frozen for only 2 weeks longer ( 24 weeks in total) cohesion was already about 49 times higher than in the control samples. Additionally, it should be noted that in each case frozen samples were characterized by a different method of destruction (occurrence of peak and residual strength), while control samples were destroyed in a plastic manner.

\section{Determination of heating pile displacement during it exploitation in the numerical analyzes}

Numerical analyzes of the heating pile displacements during its exploitation were carried out in the Z Soil v. 11.07 program using the finite element method. Their goal was to determine friction values on the side surface of pile in changing temperature conditions. A simple 2D numerical axisymmetric model built thanks to the Coulomb-Mohr theory mapped the interaction of the pile model with a homogeneous ground, whose parameters corresponded to the studied clay (Fig. 5). 


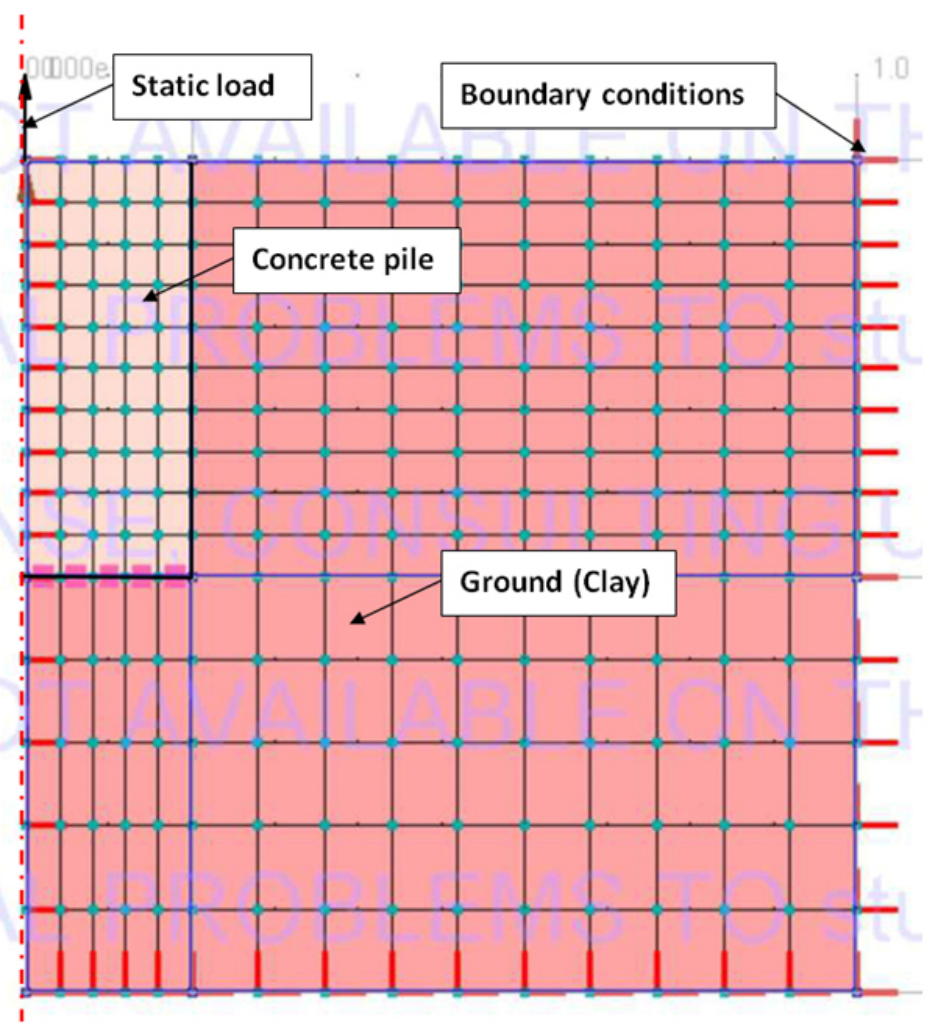

FIGURE 5. Numerical, axisymmetric model 2D

The assumed model with dimensions $1.0 \times 1.0 \mathrm{~m}$ consisted of a concrete pile with a diameter of $0.2 \mathrm{~m}$ and a length of $0.5 \mathrm{~m}$. The dimensions of the model have been so good to reflect the work of the model used during laboratory tests. The size of the soil was increased due to thermal conditions obtained in the laboratory tests. The dimensions of the pile were selected in such a way that it could be reproduced in planned model laboratory tests. The area of the model is divided into 225 finite elements. The load was applied in steps of $0.1 \mathrm{kN}$. The material parameters defined in the program corresponded to those determined in the own research. The static analysis was preceded by the analysis of the heat flow between the pile and the soil. It was assumed that at the edge of the model the temperature is $+20^{\circ} \mathrm{C}$, and on the axis of the pile, depending on the case considered $-15^{\circ} \mathrm{C}$ or $+80^{\circ} \mathrm{C}$. Then, analysis of the coupled problem was carried out, taking into account the temperature field with the ground deformation field. The calculations showed (Table 2) that in each of the analyzed cases (both during the transfer and extraction of heat from the ground), the settlement of the pile was smaller than in the absence of such a flow. The difference was $0.12 \mathrm{~mm}$, which corresponded to $32 \%$ of the settlement value of the control pile. At the 
TABLE 2. Obtaining values of pull out forces, friction on the side surface and displacement of piles - numerical analysis

\begin{tabular}{|l|c|c|c|c|c|c|}
\hline \multirow{2}{*}{$\begin{array}{l}\text { Experimental } \\
\text { situation }\end{array}$} & Pullforce & $\begin{array}{c}\text { Pile } \\
\text { weight }\end{array}$ & $\begin{array}{c}\text { Friction on the } \\
\text { side surface } \\
\text { for the control } \\
\text { pile }\end{array}$ & $\begin{array}{c}\text { Difference } \\
\text { between } \\
\text { control and } \\
\text { heating pile }\end{array}$ & $\begin{array}{c}\text { Difference } \\
\text { between } \\
\text { control and } \\
\text { heating pile }\end{array}$ & $\begin{array}{c}\text { Displace- } \\
\text { ment }\end{array}$ \\
\cline { 2 - 7 } & $\mathrm{kN}$ & $\mathrm{kN}$ & $\mathrm{kN} / \mathrm{m}^{2}$ & $\mathrm{kN} / \mathrm{m}^{2}$ & $\%$ & $\mathrm{~mm}$ \\
\hline $\begin{array}{l}\text { Lack of heat flow } \\
\text { (control pile) }\end{array}$ & 5.6 & & 17.825 & - & - & 0.375 \\
\hline $\begin{array}{l}\text { Transfer of heat } \\
\text { from ground } \\
\text { (heating pile in } \\
\text { winter) }\end{array}$ & 4.9 & \multirow{2}{*}{0.393} & 15.597 & 2.228 & 12.50 & 0.255 \\
\cline { 1 - 4 } $\begin{array}{l}\text { Extraction of heat } \\
\text { to ground (heating } \\
\text { pile in summer) }\end{array}$ & 5.0 & & 15.915 & 1.910 & 10.72 & 0.255 \\
\cline { 5 - 7 } & & & & & & \\
\hline
\end{tabular}

same time, the corresponding maximum forces that can be transferred by foundation piles were also smaller compared to the control pile. For example, in the case of ground heat recovery, the forces were $0.7 \mathrm{kN}$ lower and $0.6 \mathrm{kN}$ for the case with heat transfer to the ground. The difference between the value of friction on the side surface for the control pile - without heat flow, and the pile in which the heat is extracted from the ground, when pulling a pile out, was up to $12.5 \%$.

\section{CONCLUSIONS}

A dualistic approach in the form of laboratory tests and numerical analyzes in solving complex geotechnical problems is necessary for a comprehensive solution to the problem. On the one hand, to properly execute the numerical model, it is necessary to define material parameters correctly. On the other hand, after performing numerical calculations, the obtained results should be verified, for example by model control tests. If they are compatible with each other, it can be stated that the problem has been thoroughly verified and solved. In addition, conducting numerical analyzes allows to limit the number of experimental tests, because it gives greater possibilities to change assumptions, the test program, the load system during the test, which is not always possible in the case of experimental research.

As the own analyses showed, to obtain the most reliable results, material parameters determined in laboratory (or in situ) tests should be used. This approach is in line with the provisions of the standard (Antosz 2017). The triaxial studies presented in this work are very interesting. They showed that the increase in shear strength of the clay under conditions without drainage and the nature of the destruction depend strongly on the sample freezing time (from 2 to 24 weeks). The authors are aware that during the shearing the external conditions were not kept constant, i.e. constant temperature in the chamber of the apparatus, which changed 
from $-18^{\circ}$ to $-3^{\circ} \mathrm{C}$. Currently, work is underway to solve this problem. Another objective will be to carry out a series of tests that would confirm whether the observed relationships occur in any situation, when the soil has a constant negative temperature, and not only under conditions of its continuous growth, up to a temperature close to $0^{\circ} \mathrm{C}$.

The research carried out aimed at reflecting the actual interaction of the foundation heating pile and ground system. Such a system is exposed to constant temperature fluctuations over time. Interestingly, although the strength of the clay together with the increase of the negative temperature resulting from the length of freezing increased, the load carrying capacity of piles located in such a ground decreased while simultaneously reducing their settlements. This is the case both in acquiring heat from the ground, and in returning it to the ground. Therefore, additional safety factors should be applied when designing foundations in which the heating piles are located. Determining the exact value of such coefficients will be the goal of further research.

\section{REFERENCES}

AMIS T., BOURNE-WEBB P., DAVIDSON C., AMATYA B., SOGA K. 2008: An investigation into the effects of heating and cooling energy piles whilst under working load at Lambeth College. In: Proceedings 11th Int. Conf. Deep Foundations, 15-17.10. 2008 New York. Deep Foundation Institute [CD].

ANTOSZ K. 2017: Wpływ zmian temperatury na parametry wytrzymałościowe gruntów spoistych na podstawie badań trójosiowych typu UU [Influence of temperature changes on the strength parameters of cohesive soils based on triaxial tests UU]. Master's thesis, The
Silesian University of Technology, Gliwice [in Polish, typescript].

GRYGLASZEWKI P. 2006: Wybrane Tablice Cieplne (materiały pomocnicze do ćwiczeń z Termodynamiki i Wymiany Ciepła) [Selected Heat Tables (subsidiary materials for Thermodynamics and Heat Exchange exercises)]. Politechnika Krakowska, Kraków [in Polish]. Retrieved from http://solis.pl/index.php/projektowanie_instalacji/instalacje_zrodla/pojemnosc cieplna gruntu.

JASTRZ̄ĘBSKA M., PIOTROWICZ B. 2015: Produkcja energii cieplnej w pompach ciepła $z$ sondą gruntową zamontowaną $w$ fundamentach pośrednich obiektów budowlanych, w szczególności instalacji opartych o odnawialne źródła energii [The production of thermal energy in heat pumps with ground collector mounted in the deep foundations of the buildings, in particular the installations based on renewable energy sources]. In: B. Bochentyn, K. Piech (Eds.), Energetyka dla budownictwa - spojrzenie młodych naukowców [Energy for construction - the view of young scientists]. Creativetime, Kraków: 158-166 [in Polish].

JASTRZĘBSKA M., WAWRZYŃCZYK B. 2016: The analysis of the direct foundation with energy foundations on the basis of the office building A4 Business Park in Katowice at Francuska Street. Arch. Civ. Eng. Environ. 9 (2): 65-76.

KAPUŚCIŃSKI J., RODZOCH A. 2010: Geotermia niskotemperaturowa $\mathrm{w}$ Polsce $\mathrm{i}$ na świecie: stan aktualny i perspektywy rozwoju: uwarunkowania techniczne, środowiskowe i ekonomiczne [Low-temperature geothermics in Poland and in the world: up to date condition and development prospects: technical, environmental and economical conditioning]. $\mathrm{PhD}$ thesis. Borgis, Warszawa [in Polish].

KĘPIŃSKA B. 2015: Geothermal Energy Country Update Report from Poland, 2010-2014. Proceedings of World Geothermal Congress, 19-25.04.2015 Melbourne: 1-11.

LACHMANN P., MIROWSKI A., OCZOŚ A., KARCZMARZYK A., SAWICKI C., KOCZOROWSKI J., SMUCZYŃSKA M., FRANKE M., ZBROJKIEWICZ S. 2013: Wytyczne projektowania, wykonania i odbioru instalacji $\mathrm{z}$ pompami ciepła [Guidelines for designing the execution and acceptance of installations 
with heat pumps]. Polska Organizacja Rozwoju Technologii Pomp Ciepła PORT PC, Kraków [in Polish].

MIZERSKI W., ŻUKOWSKI J. 2001: Tablice geograficzne [Geographical tables]. Adamantan, Warszawa [in Polish].

PAJĄK L., MALINOWSKI Z. 2001: Wymiana ciepła $\mathrm{w}$ gruncie cieplnie eksploatowanym [Heat exchange in heattreated ground]. Ciepłownictwo, Ogrzewnictwo, Wentylacja 5: 12-16 [in Polish].

PIĘTKOWSKI R., CZARNOTA-BOJARSKI R. 1964: Mechanika gruntów [Soils mechanic]. Arkady, Warszawa [in Polish].

PISARCZYK S. 1998: Wplyw temperatury na właściwości fizyczne i mechaniczne gruntów [Influence of temperature on physical and mechanical properties of soils]. Pr. Nauk. PW Inż. Środ. 25: 5-18 [in Polish].

PLEWA L. 1994: Rozkład parametrów geotermalnych na obszarze Polski [Distribution of geothermal parameters in Poland]. CPPGSMiE PAN, Kraków [in Polish].

Solaris 2004-2009: Pojemność cieplna gruntu. Retrieved form http://solis.pl/index.php/projektowanie_instalacji/instalacje_zrodla/pojemnosc_cieplna_gruntu.

STEFAN̄OWICZ E., SZULGOWSKA-ZGRZYWA M. 2017: Konfiguracja odwiertów oraz obciążenie cieplne i chłodnicze obiektu, a parametry pracy dolnego źródła pompy ciepła glikol/woda [The boreholes configuration and the warming and cooling load of the building, and the work parameters of the lower source of the heat pump type glycol/ water]. Rynek Instalacyjny 3 [in Polish]. Retrieved from (http://www.rynekinstalacyjny. $\mathrm{pl} /$ artykul/id4183,konfiguracja-odwiertoworaz-obciazenie-cieplne-i-chlodnicze-obiektu-a-parametry-pracy-dolnego-zrodla-pompyciepla-glikolwoda?print $=1$.

USOWICZ B. 2002: Szacowanie cieplnych właściwości gleby [Estimation of soil thermal properties]. Acta Agroph. 72: 135-165 [in Polish].

WAJMAN M. 2011: Podstawy teoretyczne wymiany ciepła w sondach pionowych (Theoretical basis of heat transfer in vertical probes). Technika Chłodnicza i Klimatyzacyjna 9: 438-444 [in Polish].
WANG C., LIU H., KONG G., WAI C. 2017: Different types of energy piles with heating-cooling cycles. Proceedings of the Institution of Civil Engineers. Geotech. Eng. 170 (3): 220-231.

Streszczenie: Wyznaczanie parametrów numerycznych modelu pala grzewczego na podstawie laboratoryjnych testów wytrzymatościowych itu $w$ niskiej temperaturze. Pale grzewcze łączą funkcję fundamentu i źródła ciepła. Pozyskują one ciepło z gruntu poprzez wbudowaną instalację, wewnątrz której znajduje się niezamarzający płyn o niskiej temperaturze. W związku z powyższym zarówno pale, jak i otaczający grunt są narażone na znaczne zmiany temperatury. W rezultacie parametry mechaniczne gruntu oraz zachowanie powierzchni styku pal - podłoże gruntowe ulegają zmianie. Wpływa to bezpośrednio na nośność pali grzewczych. Aby określić ten efekt, przeprowadzono testy laboratoryjne w celu wyznaczenia parametrów termicznych i mechanicznych gruntu w niskiej temperaturze. Wyniki uzyskane podczas badań laboratoryjnych zadano jako parametry materiałowe gruntu w programie Z_Soil. W wyniku analizy metodą elementów skończonych stwierdzono niekorzystny wpływ na tarcie na powierzchni pala związane z przenoszeniem ciepła między materiałami.

Stowa kluczowe: pale grzewcze, przepływ ciepła, zamarzanie podłoża, analizy numeryczne, parametry wytrzymalościowe gruntu

\section{$M S$ received 02.02.2018}

\section{MS accepted 04.06.2018}

\section{Authors' address:}

Bartosz Piotrowicz, Małgorzata Jastrzębska, Marian Łupieżowiec

Katedra Geotechniki i Dróg

Wydział Budownictwa

Politechnika Śląska

ul. Akademicka 5, 44-100 Gliwice

Poland

e-mail: bartosz.piotrowicz@polsl.pl malgorzata.jastrzebska@polsl.pl marian.lupiezowiec@polsl.pl 